\title{
JRPR - New Co-published Journal of KARP, JHPS, and ARPS
}

Chan Hyeong Kim, Editor-in-Chief, JRPR

Department of Nuclear Engineering, Hanyang University, Seoul, Korea

\section{Editorial}

\footnotetext{
This is an Open-Access article distributed under the terms of the Creative Commons Attribution NonCommercial License (http://creativecommons.org/ licenses/by-nc/4.0) which permits unrestricted noncommercial use, distribution, and reproduction in any medium, provided the original work is properly cited.

Copyright $\odot$ 2019The Korean Association for Radiation Protection
}

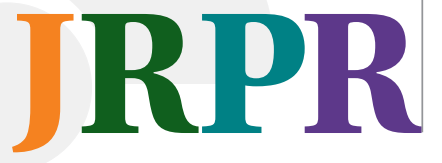

The editorial committee of the Journal of Radiation Protection and Research (JRPR) is pleased to announce that, starting from this issue (September 2019), the JRPR is copublished by three societies - the Korean Association for Radiation Protection (KARP), the Japan Health Physics Society (JHPS), and the Australasian Radiation Protection Society (ARPS) - as the official journal of the three societies.

Recently, KARP's president, Prof. Woo-Yoon Park, proposed to make the JRPR, which had been KARP's journal for more than 30 years, an international journal. Then, at the 5th Asian and Oceanic Congress on Radiation Protection (AOCRP-5) held in Melbourne, Australia in 2018, the presidents of the three societies agreed to adopt the JRPR as their joint, co-published journal. Since then, the editorial committee, the journal homepage, and all related documents have been revised to reflect the change.

JRPR's Editorial Committee now comprises three Editors-in-Chief representing the three societies, respectively, twelve Editors from the three societies (4 each), fifteen International Editors from foreign societies, and a Managing Editor in Korea who will run the JRPR on a daily basis. The JRPR, in order to broaden its global scope, will try to appoint International Editors from at least 12 foreign societies.

The purpose of the JRPR is to disseminate scientific and technical information on radiation protection and related issues, covering both ionizing and non-ionizing radiations. The topics cover radiation physics and detection, radiation dosimetry, dose monitoring and evaluation, radiation biology and epidemiology, radiation risk assessment, radiation public health and environmental impacts, radiation safety and regulations, training and education, and social science and participation including social communication and risk communication.

The new co-published JRPR is an open-access journal that is published four times a year (March 31, June 30, September 30, and December 31). The official language of the journal is English.

The new JRPR is the output of a great amount of work in a relatively short time. The efforts of several members of the Editorial Committee are truly appreciated. Especially, the previous Managing Editor, Prof. Chul Hee Min, and the current Managing Editor, Prof. Geehyun Kim, are thanked for understanding the importance of a co-published international journal and for their time and effort in helping to realize it. Special thanks also go to Dr. Moon Hee Han, the previous Editor-in-Chief, both for his long service with the former JRPR and for his time and effort in helping to establish the new journal.

It is believed that the new co-published JRPR, along with the well-established Asian and Oceanic Congress on Radiation Protection (AOCRP), will significantly enhance the exchange of scientific knowledge and experience in radiation protection among researchers in Asia, Oceania, and the entire world. 